Merck, Novartis, Pfizer, UCB, Grant/research support from: Abbott, Bristol Myers Squibb, Celgene, Celltrion, Chugai, Johnson \& Johnson, MSD, Novartis, Pfizer, Roche, UCB Pharma, Grant/research support from: AbbVie, BMS, Celgene, Chugai, Merck, Novartis, Pfizer, UCB, Grant/research support from: Abbvie (Abbott), Amgen, Baxter, Biogen, BMS, Boehringer Celgene, Celltrion, Centocor, Chugai, Hexal, Janssen, Lilly, Medac, MSD (Schering-Plough), Mylan, Mundipharma, Novartis, Pfizer (Wyeth, Hospira), Roche, Sanofi-Aventis and UCB, Consultant for: Abbvie (Abbott), Amgen, Baxter, Biogen, BMS, Boehringer, Celgene, Celltrion, Centocor, Chugai, Hexal, Janssen, Lilly, Medac, MSD (Schering-Plough), Mylan, Mundipharma, Novartis, Pfizer (Wyeth, Hospira), Roche, Sanofi-Aventis and UCB, Consultant for: AbbVie, BMS, Celgene, Chugai, Merck, Novartis, Pfizer, UCB, Consultant for: Abbott, Bristol Myers Squibb, Celgene, Celltrion, Chugai, Johnson \& Johnson, MSD, Novartis, Pfizer, Roche, UCB Pharma, Speakers bureau: AbbVie, BMS, Celgene, Chugai, Merck, Novartis, Pfizer, UCB, Speakers bureau: Abbvie (Abbott), Amgen, Baxter, Biogen, BMS, Boehringer, Celgene, Celltrion, Centocor, Chugai, Hexal, Janssen, Lilly, Medac, MSD (Schering-Plough), Mylan, Mundipharma, Novartis, Pfizer (Wyeth, Hospira), Roche, Sanofi-Aventis and UCB, Speakers bureau: AbbVie, BMS, Celgene, Chugai, Merck, Novartis, Pfizer, UCB DOI: 10.1136/annrheumdis-2019-eular.5072

\section{SAT0317 INCIDENCE OF EXTRA-ARTICULAR MANIFESTATIONS IN ANKYLOSING SPONDYLITIS, PSORIATIC ARTHRITIS AND UNDIFFERENTIATED SPONDYLOARTHRITIS - RESULTS FROM A NATIONAL REGISTER-BASED COHORT STUDY}

Karin Bengtsson ${ }^{1}$, Helena Forsblad-D'elia ${ }^{1,2}$, Eva Klingberg ${ }^{1}$, Ulf Lindström ${ }^{1}$, Mats Dehlin ${ }^{1}$, Sofia Exarchou ${ }^{3}$, Anna Deminger ${ }^{1}$, Johan Askling ${ }^{4}$, Lennart T.

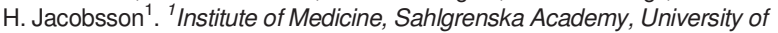
Gothenburg, Department of Rheumatology and Inflammation Research, Göteborg, Sweden; ${ }^{2}$ Umeå University, Department of Public Health and Clinical Medicine, Rheumatology, Umeå, Sweden; ${ }^{3}$ Lund University, Department of Clinical Sciences, Section of Rheumatology, Malmö, Sweden; ${ }^{4}$ Karolinska Institutet, Department of Medicine Solna, Clinical Epidemiology Unit and Rheumatology Unit, Stockholm, Sweden

Background: Spondyloarthritis (SpA), including ankylosing spondylitis (AS), psoriatic arthritis (PsA) and undifferentiated SpA (USpA), are all to varying degrees associated with extra-articular manifestations (EAMs).

Objectives: To estimate incidence rates (IRs) for EAMs (anterior uveitis, inflammatory bowel disease (IBD) and psoriasis) in patients with AS, PsA and $\mathrm{USpA}$, respectively.

Methods: In this nationwide cohort study, three separate cohorts of patients aged 18 to 69 years with AS ( $n=8517,68 \%$ men, mean age 47 \pm 13 years), PsA ( $n=22667,46 \%$ men, mean age $49 \pm 12$ years) and uSpA ( $n=10245,44 \%$ men, mean age $42 \pm 13$ years) were identified 2001 2015 in the Swedish National Patient Register (NPR). The follow-up began 1 January 2006, or six month after the date of the first SpA

Table 1.

\begin{tabular}{|c|c|c|c|c|c|c|}
\hline & \multicolumn{2}{|c|}{ AS } & \multicolumn{2}{|c|}{ PsA } & \multicolumn{2}{|c|}{ uSpA } \\
\hline & $\begin{array}{l}\text { Prior } \\
\text { EAM } \\
n(\%)\end{array}$ & $\begin{array}{c}\text { IRs } \\
(95 \% \mathrm{Cl})\end{array}$ & $\begin{array}{l}\text { Prior } \\
\text { EAM } \\
\mathrm{n}(\%)\end{array}$ & $\begin{array}{c}\text { IRs } \\
(95 \% \mathrm{Cl})\end{array}$ & $\begin{array}{l}\text { Prior } \\
\text { EAM } \\
\mathrm{n}(\%)\end{array}$ & $\begin{array}{c}\text { IRs } \\
(95 \% \mathrm{Cl})\end{array}$ \\
\hline \multicolumn{7}{|c|}{$\begin{array}{l}\text { ANTERIOR } \\
\text { UVEITIS }\end{array}$} \\
\hline All & $\begin{array}{l}1852 \\
(22)\end{array}$ & $\begin{array}{c}14.4(13.2- \\
15.5)\end{array}$ & $\begin{array}{c}356 \\
(1.6)\end{array}$ & $\begin{array}{c}1.7(1.5- \\
1.9)\end{array}$ & $\begin{array}{l}1498 \\
(15)\end{array}$ & $\begin{array}{c}7.7(6.9- \\
8.5)\end{array}$ \\
\hline Men & $\begin{array}{l}1315 \\
(23)\end{array}$ & $\begin{array}{c}15.8(14.3- \\
17.3)\end{array}$ & $\begin{array}{l}177 \\
(1.7)\end{array}$ & $\begin{array}{l}1.7(1.4- \\
2.0)\end{array}$ & 771 (17) & $\begin{array}{c}10.1(8.8- \\
11.5)\end{array}$ \\
\hline $\begin{array}{l}\text { Women } \\
\text { IBD }\end{array}$ & $537(20)$ & $\begin{array}{c}11.2(9.4- \\
13.1)\end{array}$ & $\begin{array}{l}179 \\
(1.5)\end{array}$ & $\begin{array}{l}1.8(1.5- \\
2.1)\end{array}$ & 727 (13) & $\begin{array}{c}6.0(5.1- \\
6.9)\end{array}$ \\
\hline All & $\begin{array}{l}615 \\
(7.2)\end{array}$ & $2.8(2.4-3.3)$ & $\begin{array}{l}504 \\
(2.2)\end{array}$ & $\begin{array}{l}1.1(0.9- \\
1.3)\end{array}$ & $\begin{array}{l}632 \\
(6.2)\end{array}$ & $\begin{array}{l}2.5(2.1- \\
2.9)\end{array}$ \\
\hline Men & $\begin{array}{l}403 \\
(7.0)\end{array}$ & $2.6(2.0-3.1)$ & $\begin{array}{l}192 \\
(1.8)\end{array}$ & $\begin{array}{c}1.0(0.8- \\
1.2)\end{array}$ & $\begin{array}{l}268 \\
(5.9)\end{array}$ & $\begin{array}{c}2.6(2.0- \\
3.2)\end{array}$ \\
\hline Women & $\begin{array}{l}212 \\
(7.7)\end{array}$ & $3.4(2.5-4.3)$ & $\begin{array}{l}312 \\
(2.6)\end{array}$ & $\begin{array}{l}1.2(1.0- \\
1.4)\end{array}$ & $\begin{array}{l}364 \\
(6.4)\end{array}$ & $\begin{array}{c}2.4(1.8- \\
2.9)\end{array}$ \\
\hline $\begin{array}{l}\text { PSORIAS } \\
\text { All }\end{array}$ & 264 & $5.6(5.0-6.3)$ & $N A$ & $N A$ & 405 & $7.7(7.0-$ \\
\hline Men & $\begin{array}{l}(3.1) \\
171 \\
(3.0)\end{array}$ & $5.4(4.7-6.2)$ & $N A$ & $N A$ & $\begin{array}{l}(4.0) \\
199 \\
(4.4)\end{array}$ & $\begin{array}{l}8.4) \\
6.9(5.9- \\
8.0)\end{array}$ \\
\hline Women & $93(3.4)$ & $6.1(4.9-7.3)$ & $N A$ & $N A$ & $\begin{array}{l}206 \\
(3.6)\end{array}$ & $\begin{array}{c}8.3(7.3- \\
9.3)\end{array}$ \\
\hline
\end{tabular}

The IRs are presented as number of EAMs per 1000 person-years at risk. NA, not applicable. diagnosis thereafter in previously undiagnosed cases, and ended at the first date of EAM, death, emigration or 31 December 2016, respectively. Both the SpA diagnoses and EAMs were identified according to specified ICD codes. Number of outcomes, person-years at risk and IRs with $95 \%$ $\mathrm{Cl}$ were calculated for each EAM and stratified by sex and age-intervals. Patients with a prior EAM in NPR before start of follow-up were excluded from that specific analysis.

Results: The IRs for each EAM are presented in Table 1. The overall highest IRs were noted for anterior uveitis in patients with AS (14.4 (13.2-15.5) per 1000 person-years at risk). Patients with PsA had considerably lower IRs for anterior uveitis (1.7 (1.5-1.9) per 1000 person-years at risk) and slightly lower IRs for IBD than patients with AS and USpA The IRs for anterior uveitis were significantly higher in men than in women in both AS and USpA.

Conclusion: IRs for EAMs clearly differed between the SpA subtypes, and especially for anterior uveitis where the IRs were by far highest in patients with AS and USpA compared to patients with PsA.

Disclosure of Interests: Karin Bengtsson: None declared, Helena Forsblad-d'Elia Grant/research support from: Unrestricted grants from Novartis outside the submitted work, Consultant for: Advisory board fees from Sandoz, Novartis and Abbvie, Speakers bureau: Lecturing fees from Novartis, Eva Klingberg Grant/research support from: Unrestricted grant from Roche, Consultant for: Novartis, Speakers bureau: Speakers fee from Lilly, Ulf Lindström: None declared, Mats Dehlin: None declared, Sofia Exarchou: None declared, Anna Deminger: None declared, Johan Askling Grant/research support from: Karolinska Institutet (JA) has or has had research agreements with the following pharmaceutical companies, mainly in the context of the ATRIS national safety monitoring programme for rheumatology biologicals: Abbvie, BMS, MSD, Eli Lilly, Pfizer, Roche, Samsung Bioepis, and UCB., Consultant for: Karolinska Institutet has received remuneration for JA participating in ad boards arranged by Lilly, Novartis, and Pfizer., Lennart T.H. Jacobsson Consultant for: LJ has received lecture and consulting fees from Pfizer, Abbvie, Novartis, Eli-Lily and Janssen

DOI:10.1136/annrheumdis-2019-eular.4422

\section{SAT0318 PREVALENCE AND PREDICTORS OF DEPRESSION AMONG PATIENTS WITH ANKYLOSING SPONDYLITIS AND PSORIATIC ARTHRITIS IN A CANADIAN REAL WORLD OBSERVATIONAL COHORT: RESULTS FROM THE COMPLETE STUDIES}

Louis Bessette $^{1}$, Majed Khraishi ${ }^{2}$, Viktoria Pavlova ${ }^{3}$, Jacqueline Stewart ${ }^{4}$, Valencia P. Remple ${ }^{5}$. 'Laval University, Centre Hospitalier de l'Université Laval, Quebec, Canada; ${ }^{2}$ Memorial University of Newfoundland, St. John's, Canada; ${ }^{3}$ McMaster University, Hamilton, Canada; ${ }^{4}$ University of British Columbia, Penticton, Canada ${ }^{5}$ AbbVie Corporation, Montreal, Canada

Background: Ankylosing pondylitis (AS) and psoriatic arthritis (PsA) are chronic inflammatory diseases known to cause physical, emotional, social and psychological impairment. However, few data are available on comorbidities such as depression and the factors associated with depression.

Objectives: To evaluate the prevalence of depression and to identify sociodemographic and disease-related factors associated with depression among PsA and AS patients.

Methods: Patients eligible for the COMPLETE studies are anti-TNFo naïve adults with active AS or PsA requiring change in their treatment regimen. In this analysis, patients enrolled between Jul/2011 - Nov/2017, treated with adalimumab or non-biologic DMARDs were included. Depression was defined as Beck's Depression Inventory (BDI) $\geq 20$ and/or patients treated with an antidepressant/anxiolytic at baseline (before treatment modification). Associated symptoms of depression were assessed with the BDI considering\% of patients with a score of 2 or 3 (moderate to severe symptoms). Univariate and multivariate logistic regression were used to identify sociodemographic and disease-related predictors associated with depression at baseline. In addition, the correlation of the BD score and the following parameters at baseline was assessed with the Pearson coefficient (r): age, disease duration, PsA disease specific parameters (28-tender [TJC] and swollen joint count [SJC], patient global assessment [PtGA], physician global assessment [MDGA]), and AS disease specific parameters (BASDAI, BASFI, morning stiffness, and number of extra-articular manifestations [EAMs]).

Results: A total of 492 AS and 333 PsA patients were included. Mean (SD) age was 42.7 (13.2) and 51.5 (12.2) years for AS and PsA, respectively, and disease duration was 5.4 (9.1) and 14.7 (13.7) years. The prevalence of baseline depression was $24.6 \%$ for AS and $25.5 \%$ for PsA. The most commonly reported symptoms of associated with depression, were loss of energy $(33.2 \%$ and $26.2 \%)$, changes in sleeping 